\title{
BIOLOGICAL CONTROL OF THE CITRUS MEALYBUG, PLANOCOCCUS CITRI (HOMOPTERA: PSEUDOCOCCIDAE) INFESTING CITRUS TREES BY SUCCESSIVE RELEASING WITH DIFFERENT LEVELS OF THE GREEN LACEWING, CHRYSOPERLA CARNEA (NEUROPTERA: CHRYSOPIDAE)
}

\author{
ASHRAF A. H. MANGOUD AND K. A. H. ALI
}

Plant Protection Research Institute, ARC, Dokki, Giza

(Manuscript received 14 July 2008)

\begin{abstract}
The green lacewing, Chrysoperla carnea Steph (Neuroptera: Chrysopidae) was successively released (with three levels), 5, 10 and 15 larvae/tree at late April, late May and late June 2006 and repeated in the same times during 2007 at Gharbia Governorate. During the first season (2006), the reduction percentages in the population of the citrus mealybug, Planococcus citri (Risso) increased gradually with elapse of time. The achieved average reductions in mealybug population were $66.08,82.75$ and $98.66 \%$ at the end of July for the three releasing levels, respectively in the first year (2006). However, the same trend was achieved in the second season (2007) and reduction percentages were 56.14, 80.86 and $93.92 \%$, respectively.

Statistical analysis revealed differences in responses to the three successive releasing levels of $C$. carnea for management $P$. citri during 2006 an 2007 seasons that proved no significant among the two seasons.

The present work has shown that $C$. carnea can use successfully as a biocontrol agent in an integrated program for controlling $P$. citri attacking citrus trees.
\end{abstract}

\section{INTRODUCTION}

The citrus mealybug, Planococcus citri (Risso) (Homoptera : Pseudococcidae) is one of the most common pests on citrus. This pest has a pan tropical and subtropical region distribution. The citrus mealybug attacks citrus, cotton, vines, mango, banana and ornamental plants (Hill, 1983 \& Baker, 1998). Mealybug has become a more serious pest in recent years and difficult to control with conventional sprays because the adult is protected by a waxy covering. Female usually deposite from 200 to 600 eggs. Eggs are laid in groups covered by a dense, fluffy, white mass of wax called the ovisac; therefore, the mealybugs are not easy to be control by pesticides. The citrus mealybug has a toxin in its saliva, which causes drop of leaves and buds of its host plants. Infested plants usually die unless this pest is controlled (Baker, 1998). Large infestations cause fruit drop and reduce yields, but their greatest damage by secretion of honeydew on fruit and leaves. Sooty moulds often grow on the honeydew causing 
infested plants to turn black and associated sooty mould fungus reduce fruit quality and vitality of citrus trees (Cartwirth and Browning, 1999).

The green lacewing, Chrysoperla carnea Steph. (Neuroptera: Chrysopidae) is an aphid's predator very common in nature. Only the larval stages can feed on different insect species, (larvae have a ferocious appetite for aphids, mealybugs, immature scales and whiteflies, thrips, spider mites and other plant pests), while the adult usually feeds on nectar, honeydew and other sugar sources. The adult female lay eggs right in the middle of an insect colony, the larvae are pale brown or grey and start preying after emergence (Ridgway and Vinson, 1977).

The present work aimed to evaluate successive releasing of the green lacewing, C. carnea to management the citrus mealybug, $P$. citri on citrus trees at Gharbia Governorate.

\section{MATERIALS AND METHODS}

\section{Rearing of chrsoperla carnea}

C. carnea adults were collected from the field by insect sweeping net and brought to the laboratory. The collected adults were put in chimney glass $(17 \mathrm{~cm}$ height, $7 \mathrm{~cm}$ top diameter and $8.5 \mathrm{~cm}$ bottom diameter). The bottom of each chimney cage was placed on a Petri-dish and its top was covered with black muslin for laying their eggs and kept in position by rubber bands (Ali, 2003).

The artificial diet for adults was prepared by adding yeast oxido : fructose sugar: water as a ratio $5: 6: 10$ and put together in a beaker, which mixed with a mixer. The diet should be a viscous pulp, which is easy to spread using a brush or spatula. A piece of cotton with the mixture (artificial diet) was offered to adults. Adults laying their eggs on the muslin cloth on their stalks glued. Eggs were collected daily by scissors and newly black muslin cloth was replaced. The larvae are fed preferable with fresh eggs of $P$. citri which was supplied until pupation.

\section{Successive release of $C$. carnea}

The $2^{\text {nd }}$ larval instars of $C$. carnea were released. Envelops (A4 size) were used for transporting the predator, each envelop containing a white A4 paper sheets displaying the predator and facing of papers each other, so that reduce the cannibalism between them and the larvae could be freely; each envelope containing the accurate number of the $2^{\text {nd }}$ larvae instars $\left(L_{2}\right)$. Three levels of $C$. carnea $(5,10$ and 15 larvae/tree) were released by brushing the $L_{2}$ on the infesting sites of the tree using a fine and smooth camel's brush. In each level three times of release evere made according to the obtained results from each one, at late April, late May and late 
June 2006 and repeated in the same times during 2007. Successive releasing study was conducted on citrus trees, at Gharbia Governorate. The selected trees for the present investigation were away from any pesticide contamination. The trees were about 20 years old, with about 5-6 meters in height, similar in size, age, shape, and vegetation as possible and had approximately similar infestation by $P$. citri.

The citrus trees were divided into 4 replicates; 4 trees each (16 trees) for each plot. Another 16 trees were selected to be as a check plot.

Leaf samples (30 leaves/sample) were selected at random from all parts of the tree. Leaves were kept in paper bags and transferred to the laboratory for stereomicroscopic examination. The upper and lower leaf surfaces were inspected and the alive nymphs and adult females and their predators were counted.

\section{Statistical analysis}

The reduction percentage of infestation by mealybugs and number of predators was calculated according to the equation of Henderson and Tilton (1955). The data was subjected to analysis of variance (ANOVA) and the means were compared by L.S.D. test at 0.05 level using SAS program (SAS Institute, 1988).

\section{RESULTS AND DISCUSSION}

The mealybugs are not easy to control by pesticides because the eggs are enmeshed in the waxy fluff, it is difficult to get a pesticide through to kill them (Baker, 1998) therefore in this work chrysoperla carnea predator was released with different levels to management the infestation by the mealybug, $P$. citri.

\section{First year (2006)}

\subsection{First level of release ( 5 larvae/tree)}

The first level of release was occurred on the late April the $1^{\text {st }}$ releasing time. The pre-count in the releasing area with mealybug was 55.7 individuals/leaf, while it was also 61.8 individuals/leaf in check trees.

The results in Fig. (1) indicated that the number of $P$. citri in the $1^{\text {st }}$ release plot decreased gradually from 55.7 on late April to 52.3, 50.1, 48.7 and 45.2 individuals/leaf after $1^{\text {st }}, 2^{\text {nd }}, 3^{\text {rd }}$ and $4^{\text {th }}$ week of May, respectively as compared to check plot where mealybug populations changed from 61.8 individuals/leaf on late April to $66.4,71.6,78.5$ and 79.2 individuals/leaf in the same dates, respectively. In addition, the results show that the percent reduction of mealybug population in $1^{\text {st }}$ release plot increased gradually to reach $12.61,22.36,31.17$ and $36.68 \%$ on the $1^{\text {st }}$, $2^{\text {nd }}, 3^{\text {rd }}$ and $4^{\text {th }}$ week of May, respectively. 
The second releasing time was occurred (after finishing the last inspection of the $1^{\text {st }}$ release level) on late May; the pre-count in the releasing area with mealybug was 45.2 individuals/leaf, while it was 79.2 individuals/leaf in check trees. The results in Fig. (1) indicated that the number of $P$. citri in the $1^{\text {st }}$ release plot decreased gradually from 45.2 on late May to $41.8,31.2,21.8$ and 14.7 individuals/leaf on the $1^{\text {st }}, 2^{\text {nd }}, 3^{\text {rd }}$ and $4^{\text {th }}$ week of June, respectively as compared to check plot (where mealybug populations changed from 79.2 individuals/leaf on late May to 82.4, 74.5, 66.7 and 55.6 individuals/leaf in the same dates, respectively. In addition, the results show that the percent reduction of mealybug population in $1^{\text {st }}$ release plot increased gradually to reach $11.11,26.62,42.73$ and $53.67 \%$ on the $1^{\text {st }}, 2^{\text {nd }}, 3^{\text {rd }}$ and $4^{\text {th }}$ week of June, respectively.

Also, the third releasing time occurred (after finishing the last inspection of the $2^{\text {nd }}$ release level) on late June; the pre-count in the releasing area with mealybug was 14.7 individuals/leaf, while it was also 55.6 individuals/leaf in check trees. The results in Fig. (1) indicated that the number of $P$. citri in the $1^{\text {st }}$ release plot decreased gradually from 14.7 on late June to $9.8,7.9,6.8$ and 5.3 individuals/leaf on the $1^{\text {st }}$, $2^{\text {nd }}, 3^{\text {rd }}$ and $4^{\text {th }}$ week of July, respectively as compared to check plot where mealybug populations changed from 55.6 individuals/leaf on late June to $42.8,46.7,53.2$ and 59.1 individuals/leaf in the same dates, respectively. In addition, the results show that the percent reduction of mealybug population in $1^{\text {st }}$ release plot increased gradually to reach $13.39,36.02,51.65$ and $66.08 \%$ on the $1^{\text {st }}, 2^{\text {nd }}, 3^{\text {rd }}$ and $4^{\text {th }}$ week of July, respectively.

The results agreed with those obtained by (Anonymous, 2006) who found control of the light mealybug infestation by releasing the $2^{\text {nd }}$ larval instars with rate 23 larvae/ $\mathrm{m}^{2}$ or $10-12$ larvae/ $\mathrm{m}^{2}$ for control of heavy mealybug populations and make 3-4 releases at 2-3 week intervals. Also found that $C$. carnea do best in warm, humid conditions. In addition, the results agreed with finding Ortu and Marras, (1999) who found that $C$. montrouzieri are particularly efficient at controlling the mealybugs where insecticides do not easily penetrate.

\subsection{Second level of release ( 10 larvae/tree)}

In second level, the $1^{\text {st }}$ releasing time occurred on late April; the pre-count in the releasing area with mealybug was 41.9 individuals/leaf, while it was also 43.7 individuals/leaf in check trees.

The results in Fig. (2) indicated that the number of $P$. citri in the $2^{\text {nd }}$ release plot decreased gradually from 41.9 on late April to 36.5, 25.8, 23.1 and 19.4 individuals/leaf on the $1^{\text {st }}, 2^{\text {nd }}, 3^{\text {rd }}$ and $4^{\text {th }}$ week of May, respectively as compared to check plot where mealybug populations changed from 43.7 individuals/leaf on late April to $48.2,52.4,56.1$ and 63.7 individuals/leaf in the same dates, respectively. In addition, the results show that the percent reduction of mealybug population in $2^{\text {nd }}$ release plot increased gradually to reach $68.24 \%$ on May. 

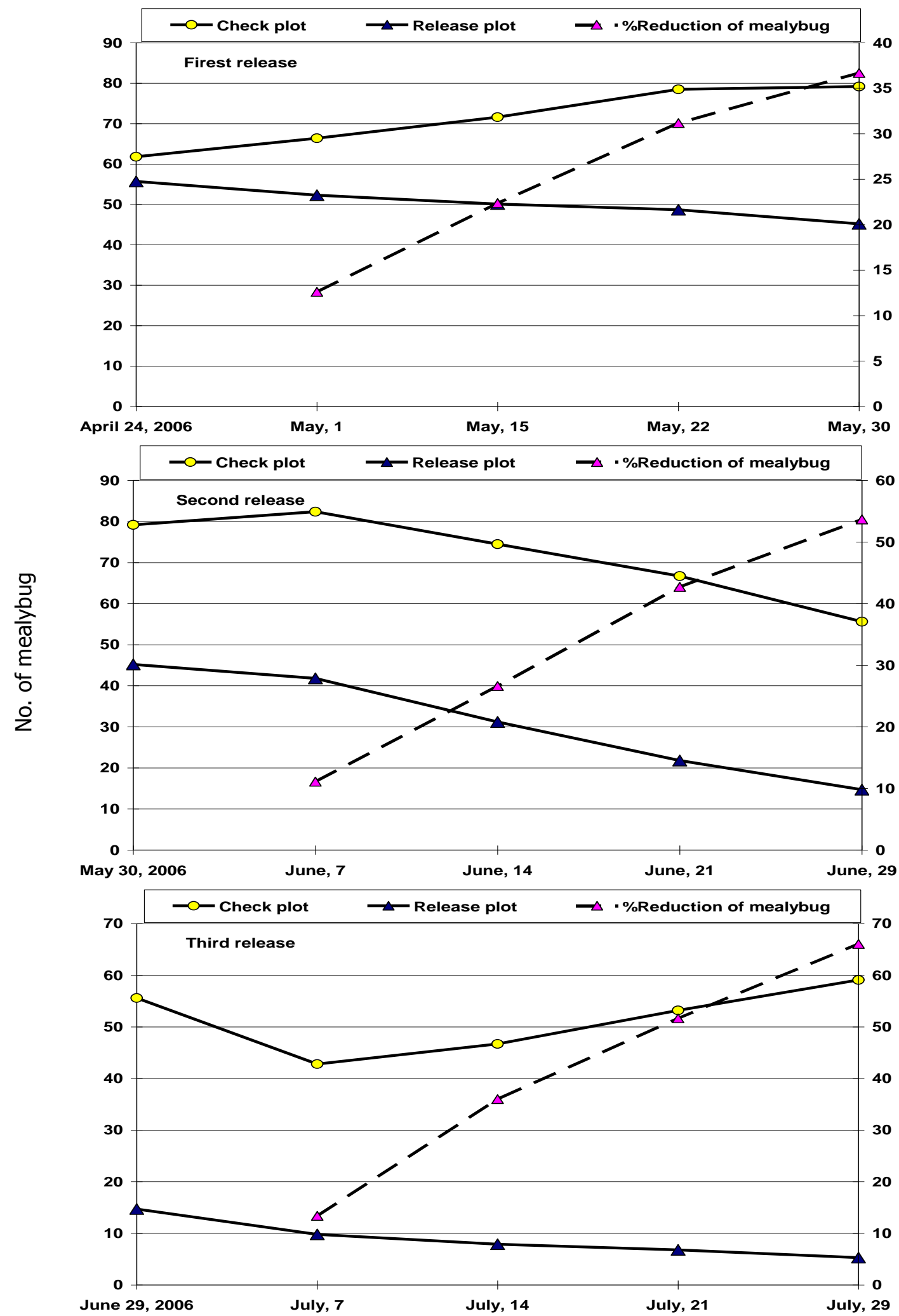

Fig. 1. Population fluctuation in the population numbers of the citrus mealybug, Planococcus citri (Risso) (Homoptera : Pseudococcidae) in the $1^{\text {st }}$ plot release at level (5 larvae/tree) of the green lacewing, Chrysoperla carnea Steph. (Neuroptera: Chrysopidae), and the corresponding \%reduction of the mealybug density on citrus trees during 2006. 
112 BIOLOGICAL CONTROL OF THE CITRUS MEALYBUG, PLANOCOCCUS CITRI (HOMOPTERA:

PSEUDOCOCCIDAE) INFESTING CITRUS TREES BY SUCCESSIVE RELEASING WITH DIFFERENT

LEVELS OF THE GREEN LACEWING, CHRYSOPERLA CARNEA (NEUROPTERA: CHRYSOPIDAE)

The second releasing time was occurred (after finishing the last inspection of the $1^{\text {st }}$ release level) on late May; the pre-count in the releasing area with mealybug was 19.4 individuals/leaf, while it was also 63.7 individuals/leaf in check trees.

The results in Fig. (2) indicated that the number of $P$. citri in the $2^{\text {nd }}$ release plot decreased gradually from 19.4 on late May to $17.3,11.3,9.4$ and 6.8 individuals/leaf on the $1^{\text {st }}, 2^{\text {nd }}, 3^{\text {rd }}$ and $4^{\text {th }}$ week of June, respectively as compared to check plot where mealybug populations changed from 63.7 individuals/leaf on late May to 61.7, 52.8 and 47.6 individuals/leaf in the same dates, respectively.

In addition, the results show that the percent reduction of mealybug population in $2^{\text {nd }}$ release plot increased gradually to reach $53.09 \%$ on June.

Also, the third releasing time occurred (after finishing the last inspection of the $2^{\text {nd }}$ release level) on late June; the pre-count in the releasing area with mealybug was 6.8 individuals/leaf, while it was also 47.6 individuals/leaf in check trees. The results in Fig. (2) indicated that the number of $P$. citri in the $3^{\text {rd }}$ release plot decreased gradually from 6.8 on late June to $4.6,3.1,2.2$ and 1.4 individuals/leaf on the $1^{\text {st }}, 2^{\text {nd }}, 3^{\text {rd }}$ and $4^{\text {th }}$ week of July, respectively as compared to check plot where mealybug populations changed from 47.6 individuals/leaf on late June to $44.1,46.6,53.2$ and 56.8 individuals/leaf in the same dates, respectively. In addition, the results show that the percent reduction of mealybug population in $2^{\text {nd }}$ release plot increased gradually to reach $82.75 \%$ on July.

\subsection{Third level of release (15 larvae/tree)}

In third level of release, the first releasing time occurred on late April; the precount in the releasing area with mealybug was 53.2 individuals/leaf, while it was also 55.6 individuals/leaf in check trees. 

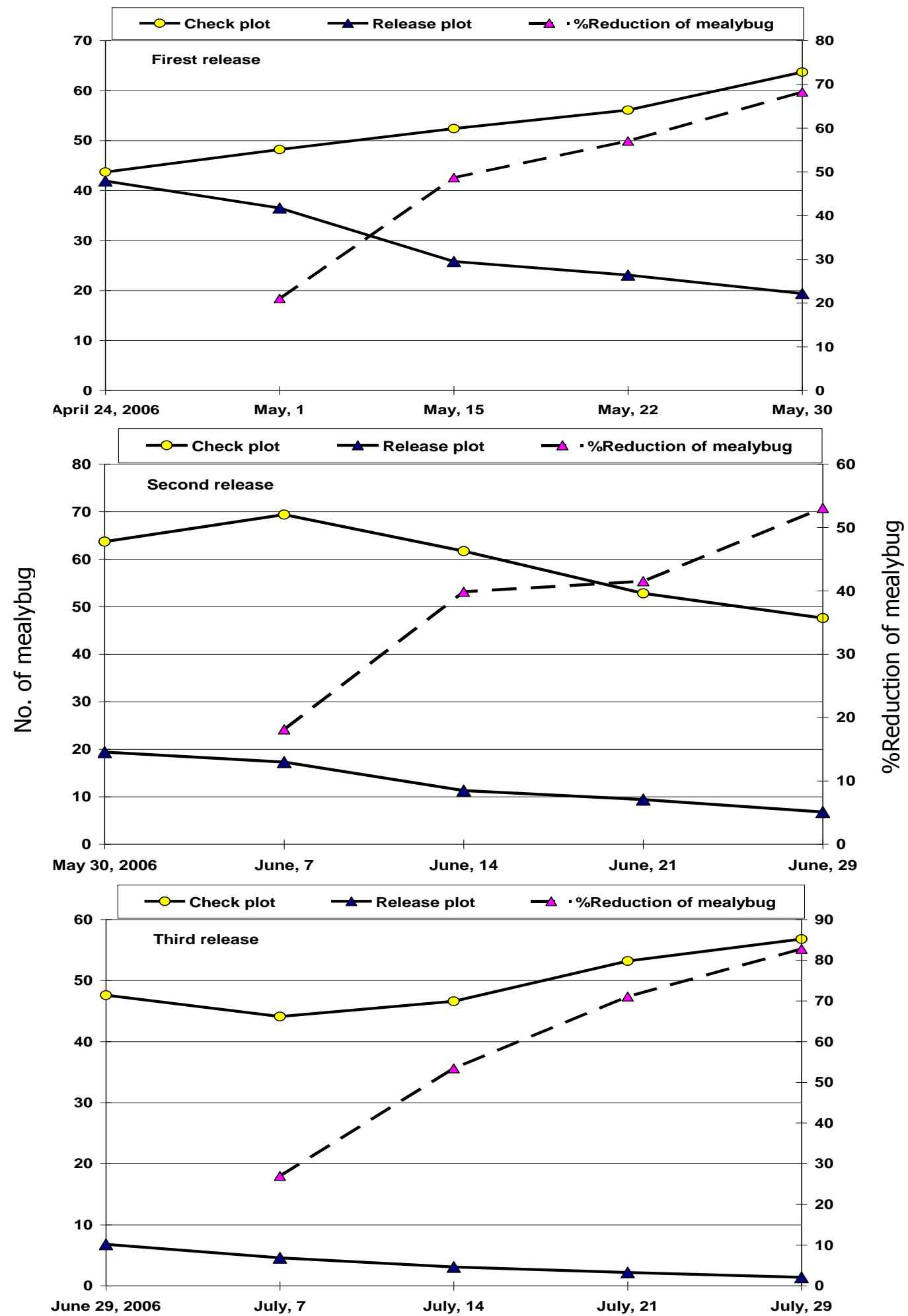

Fig. 2. Population fluctuation in the population numbers of the citrus mealybug, Planococcus citri (Risso) (Homoptera : Pseudococcidae) in the $2^{\text {nd }}$ plot release at level (10 larvae/tree) of the green lacewing, Chrysoperla carnea Steph. (Neuroptera: Chrysopidae), and the corresponding \%reduction of the mealybug density on citrus trees during 2006. 
114 BIOLOGICAL CONTROL OF THE CITRUS MEALYBUG, PLANOCOCCUS CITRI (HOMOPTERA: PSEUDOCOCCIDAE) INFESTING CITRUS TREES BY SUCCESSIVE RELEASING WITH DIFFERENT LEVELS OF THE GREEN LACEWING, CHRYSOPERLA CARNEA (NEUROPTERA: CHRYSOPIDAE)

The results in Fig. (3) indicated that the number of $P$. citri in the $3^{\text {rd }}$ release plot decreased gradually from 53.2 on late April to $38.1,27.5,21.3$ and 18.7 individuals/leaf on the $1^{\text {st }}, 2^{\text {nd }}, 3^{\text {rd }}$ and $4^{\text {th }}$ week of May, respectively as compared to check plot where mealybug populations changed from 55.6 individuals/leaf on late April to $58.9,64.8,69.7$ and 67.4 individuals/leaf in the same dates, respectively. In addition, the results show that the percent reduction of mealybug population in $3^{\text {rd }}$ release plot increased gradually to reach $71.00 \%$ on May.

The second releasing time occurred (after finishing the last inspection of the $1^{\text {st }}$ release level) on late May; the pre-count in the releasing area with mealybug was 18.7 individuals/leaf, while it was also 67.4 individuals/leaf in (check trees).

The results in Fig. (3) indicated that the number of $P$. citri in the $3^{\text {rd }}$ release plot decreased gradually from 18.7 on late May to $14.8,11.8,9.1$ and 5.1 individuals/leaf on the $1^{\text {st }}, 2^{\text {nd }}, 3^{\text {rd }}$ and $4^{\text {th }}$ week of June, respectively as compared to check plot where mealybug populations changed from 67.4 individuals/leaf on late May to 61.9, 54.8, 48.7 and 41.5 individuals/leaf in the same dates, respectively. In addition, the results show that the percent reduction of mealybug population in $3^{\text {rd }}$ release plot increased gradually to reach $55.71 \%$ on June.

The third releasing time occurred (after finishing the last inspection of the $2^{\text {nd }}$ release level) on late June; the pre-count in the releasing area with mealybug was 5.1 individuals/leaf, while it was also 41.5 individuals/leaf in (check trees).

The results in Fig. (3) indicated that the number of $P$. citri in the $3^{\text {rd }}$ release plot decreased gradually from 5.1 on late June to $2.7,1.1,0.8$ and 0.1 individuals/leaf on the $1^{\text {st }}, 2^{\text {nd }}, 3^{\text {rd }}$ and $4^{\text {th }}$ week of July, respectively as compared to check plot where mealybug populations changed from 41.5 individuals/leaf on late June to $52.4,57.3$, 59.4 and 60.9 individuals/leaf in the same dates, respectively. In addition, the results show that the percent reduction of mealybug population in $3^{\text {rd }}$ release plot increased gradually to reach $98.66 \%$ on July.

Mendel et al. (1998) found the possibility of managing $P$. citri populations in citrus plantations by inundative releases of predators and parasitoids such as chrysoperla montrouzieri, Sympherobius sanctus, Leptomastix dactylopii and Anagyrus pseudococci. 


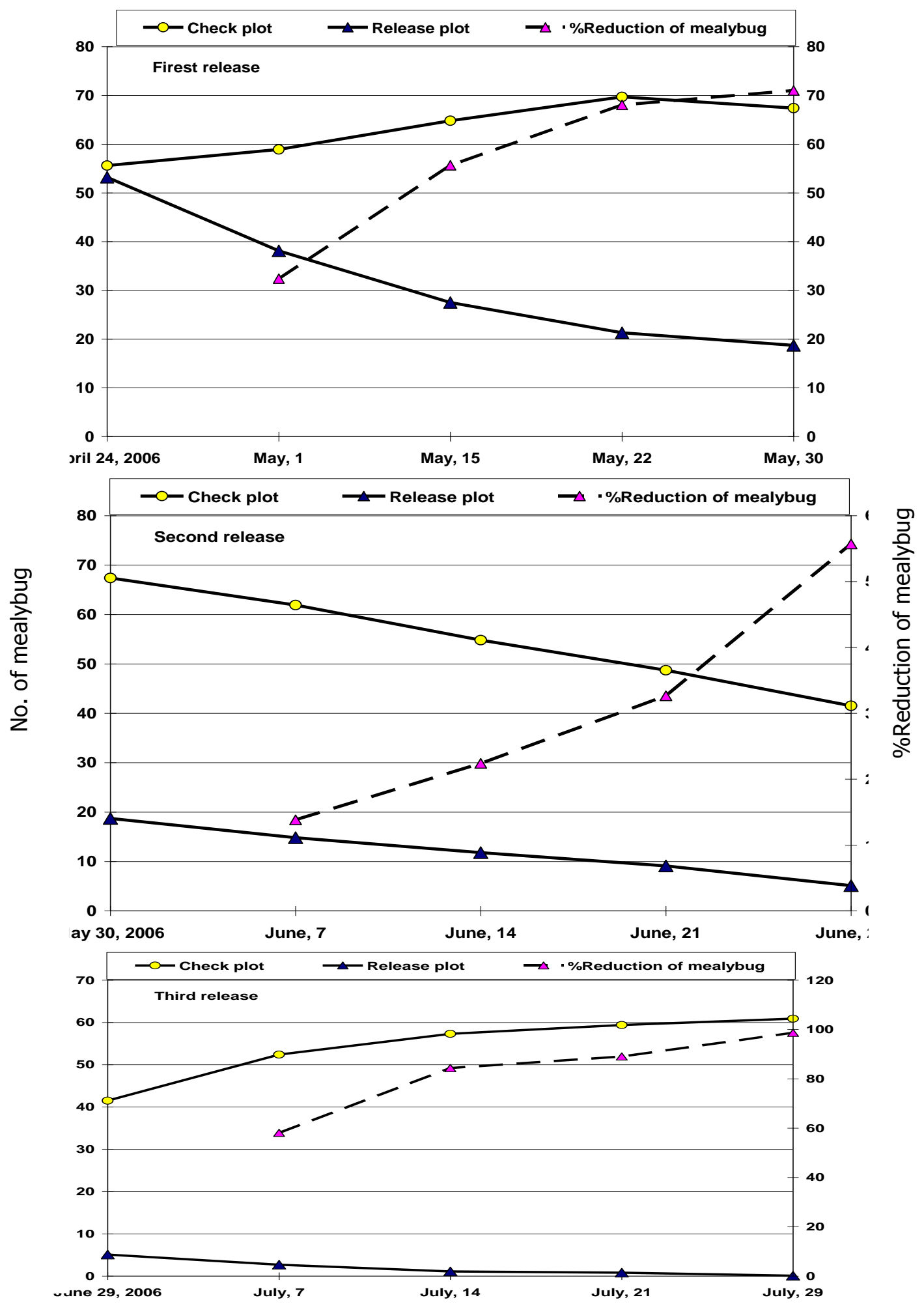

Fig. 3. Population fluctuation in the population numbers of the citrus mealybug, Planococcus citri (Risso) (Homoptera : Pseudococcidae) in the $2^{\text {nd }}$ plot release at level (15 larvae/tree) of the green lacewing, Chrysoperla carnea Steph. (Neuroptera: Chrysopidae), and the corresponding \%reduction of the mealybug density on citrus trees during 2006. 


\section{1. Second year (2007)}

\subsection{First level of release ( 5 larvae/tree)}

In first level of release, the $1^{\text {st }}$ releasing time occurred on the late April; the pre-count in the releasing area with mealybug was 46.8 individuals/leaf, while it was also 51.2 individuals/leaf in check trees plot. The results in Fig. (4) indicated that the number of $P$. citri in the $1^{\text {st }}$ release plot decreased gradually from 46.8 on late April to $43.1,40.4,39.6$ and 36.4 individuals/leaf on the $1^{\text {st }}, 2^{\text {nd }}, 3^{\text {rd }}$ and $4^{\text {th }}$ week of May, respectively as compared to check plot where mealybug populations changed from 51.2 individuals/leaf on late April to $57.4,63.1,71.6$ and 75.7 individuals/leaf in the same dates, respectively. In addition, the results show that the percent reduction of mealybug population in $1^{\text {st }}$ release plot increased gradually to reach $47.39 \%$ on May.

The second releasing time occurred (after finishing the last inspection of the $1^{\text {st }}$ release level) on late May; the pre-count in the releasing area with mealybug was 45.2 individuals/leaf, while it was also 79.2 individuals/leaf in check trees. The results in Fig. (4) indicated that the number of $P$. citri in the $1^{\text {st }}$ release plot decreased gradually from 36.4 on late May to $29.1,25.4,17.8$ and 14.1 individuals/leaf on the $1^{\text {st }}, 2^{\text {nd }}, 3^{\text {rd }}$ and $4^{\text {th }}$ week of June, respectively as compared to check plot (mealybug populations changed from 75.7 individuals/leaf on late May to 71.9, 63.2, 59.7 and 54.3 individuals/leaf in the same dates, respectively. In addition, the results show that the percent reduction of mealybug population in $1^{\text {st }}$ release plot increased gradually to reach $45.99 \%$ on June.

Also, the third releasing time occurred (after finishing the last inspection of the $2^{\text {nd }}$ release level) on late June; the pre-count in the releasing area with mealybug was 14.1 individuals/leaf, while it was also 54.3 individuals/leaf in check trees. The results in Fig. (4) indicated that the number of $P$. citri in the $1^{\text {st }}$ release plot decreased gradually from 14.1 on late June to $11.2,8.7,6.7$ and 5.9 individuals/leaf on the $1^{\text {st }}$, $2^{\text {nd }}, 3^{\text {rd }}$ and $4^{\text {th }}$ week of July, respectively as compared to check plot where mealybug populations changed from 54.3 individuals/leaf on late June to $59.2,61.7,55.2$ and 51.8 individuals/leaf in the same dates, respectively. In addition, the results show that the percent reduction of mealybug population in $1^{\text {st }}$ release plot increased gradually to reach $56.14 \%$ on July.

Mangoud (2006) under green house conditions in Germany reached to similar results and reported the efficiency of Leptomastix dactylopii Howard (Hymenoptera : Encyrtidae) and Cryptolaemus montrouzieri (Mulsant) (Coleoptera : Coccinellidae) in reducing the population of the citrus mealybug, Planococcus citri (Risso) (Homoptera : Pseudococcidae) on citrus trees. 


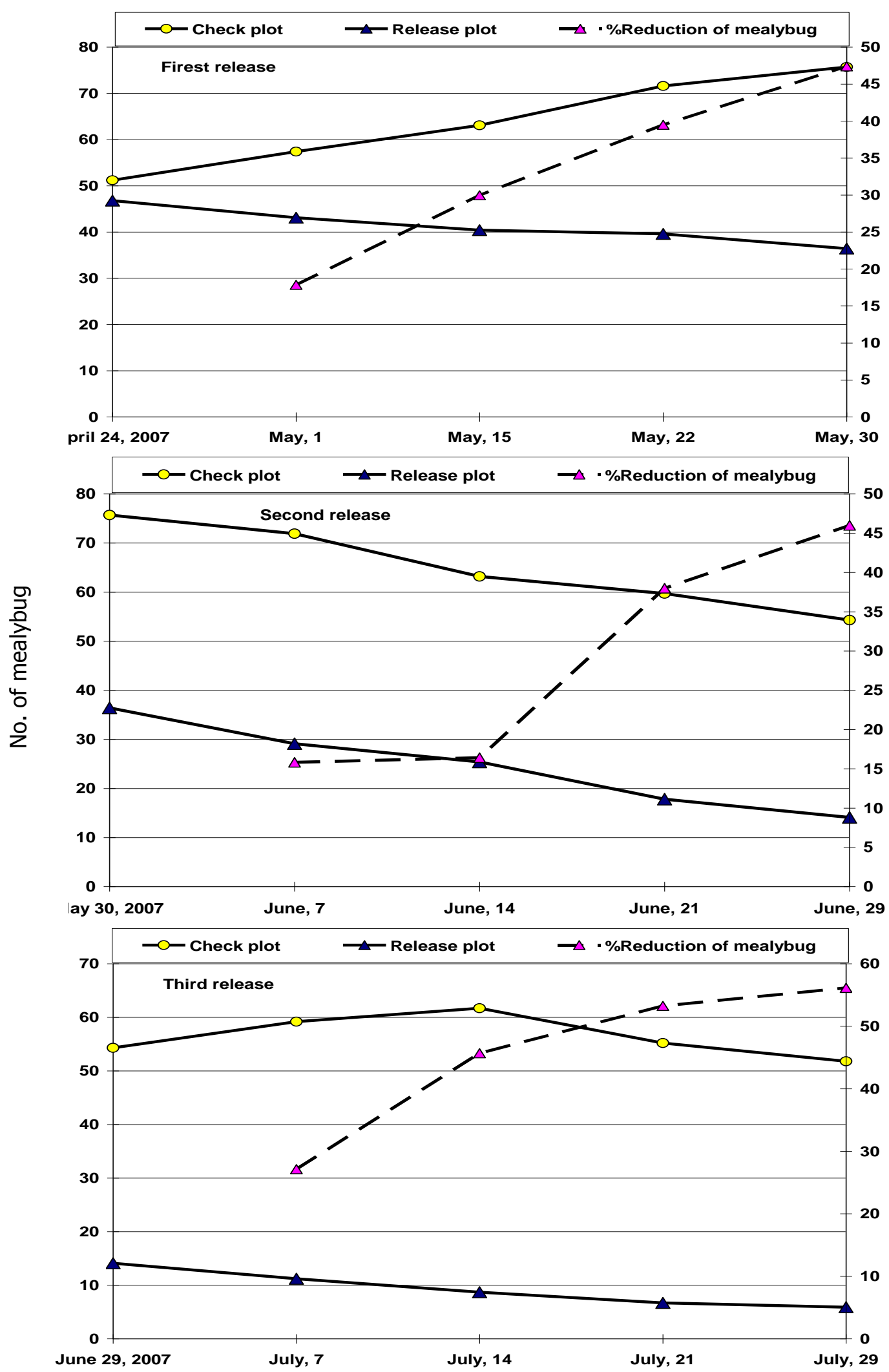

Fig. 4. Population fluctuation in the population numbers of the citrus mealybug, Planococcus citri (Risso) (Homoptera : Pseudococcidae) in the $1^{\text {st }}$ plot release at level (5 larvae/tree) of the green lacewing, Chrysoperla carnea Steph. (Neuroptera: Chrysopidae), and the corresponding \%reduction of the mealybug density on citrus trees during 2007. 


\subsection{Second level of release (10 larvae/tree)}

In second level, the $1^{\text {st }}$ releasing time occurred (after finishing the last inspection of the $1^{\text {st }}$ release level) on late April; the pre-count in the releasing area with mealybug was 52.1 individuals/leaf, while it was also 56.4 individuals/leaf in (check trees). The results in Fig. (5) indicated that the number of $P$. citri in the $2^{\text {nd }}$ release plot decreased gradually from 52.1 on late April to 41.6, 33.2, 29.3 and 25.1 individuals/leaf on the $1^{\text {st }}, 2^{\text {nd }}, 3^{\text {rd }}$ and $4^{\text {th }}$ week of May, respectively as compared to check plot where mealybug populations changed from 56.4 individuals/leaf on late April to $60.9,66.1,70.8$ and 78.5 individuals/leaf in the same dates, respectively.

In addition, the results show that the percent reduction of mealybug population in $2^{\text {nd }}$ release plot increased gradually to reach $26.05,45.63,55.20$ and $65.39 \%$ on the $1^{\text {st }}, 2^{\text {nd }}, 3^{\text {rd }}$ and $4^{\text {th }}$ week of May, respectively.

The second releasing time occurred (after finishing the last inspection of the $1^{\text {st }}$ release level) on late May; the pre-count in the releasing area with mealybug was 25.1 individuals/leaf, while it was also 78.5 individuals/leaf in check trees plot.

The results in Fig. (5) indicated that the number of $P$. citri in the $2^{\text {nd }}$ release plot decreased gradually from 25.1 on late May to $17.5,12.2,10.7$ and 7.2 individuals/leaf on the $1^{\text {st }}, 2^{\text {nd }}, 3^{\text {rd }}$ and $4^{\text {th }}$ week of June, respectively as compared to check plot where mealybug populations changed from 78.5 individuals/leaf on late May to 69.1, 61.5, 55.6 and 41.8 individuals/leaf in the same dates, respectively. In addition, the results show that the percent reduction of mealybug population in $2^{\text {nd }}$ release plot increased gradually to reach $46.13 \%$ on June.

Also, the third releasing time occurred (after finishing the last inspection of the $2^{\text {nd }}$ release level) on late June; the pre-count in the releasing area with mealybug was 7.2 individuals/leaf, while it was also 41.8 individuals/leaf in check trees plot. The results in Fig. (5) indicated that the number of $P$. citri in the $3^{\text {rd }}$ release plot decreased gradually from 7.2 on late June to $5.4,4.7,3.4$ and 2.1 individuals/leaf on the $1^{\text {st }}, 2^{\text {nd }}$, $3^{\text {rd }}$ and $4^{\text {th }}$ week of July, respectively as compared to check plot where mealybug populations changed from 41.8 individuals/leaf on late June to 49.2, 54.3, 59.1 and 63.7 individuals/leaf in the same dates, respectively. In addition, the results show that the percent reduction of mealybug population in $2^{\text {nd }}$ release plot increased gradually to reach $80.86 \%$ on July. 


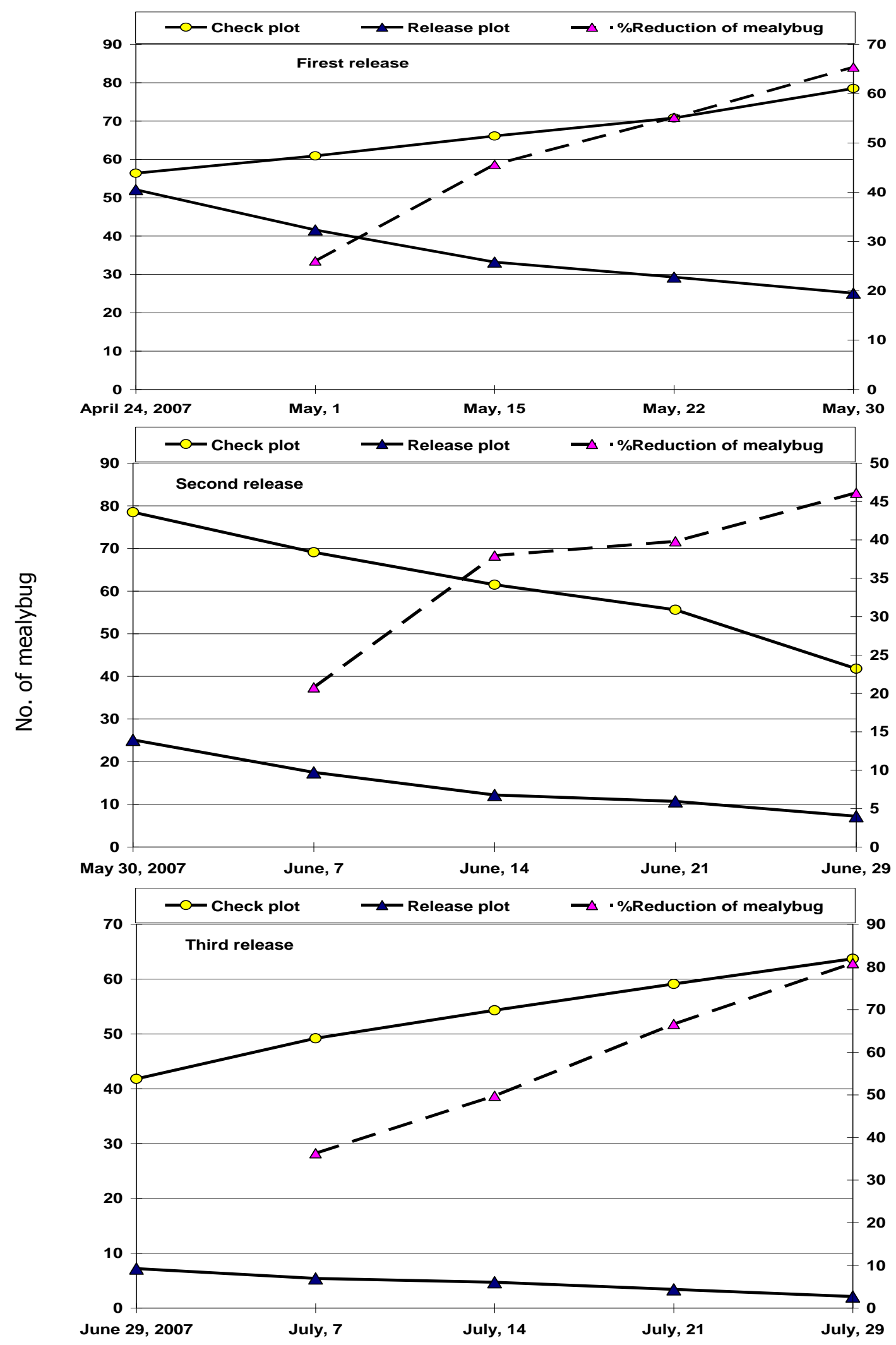

Fig. 5. Population fluctuation in the population numbers of the citrus mealybug, Planococcus citri (Risso) (Homoptera : Pseudococcidae) in the $2^{\text {nd }}$ plot release at level (10 larvae/tree) of the green lacewing, Chrysoperla carnea Steph. (Neuroptera: Chrysopidae), and the corresponding \%reduction of the mealybug density on citrus trees during 2007. 


\subsection{Third level of release (15 larvae/tree)}

In third level of release, the first releasing time occurred on the late April; the pre-count in the releasing area with mealybug was 47.4 individuals/leaf, while it was also 46.8 individuals/leaf in check trees plot. The results in Fig. (6) indicated that the number of $P$. citri in the $3^{\text {rd }}$ release plot decreased gradually from 47.4 on late April to $37.1,28.1,21.4$ and 17.3 individuals/leaf on the $1^{\text {st }}, 2^{\text {nd }}, 3^{\text {rd }}$ and $4^{\text {th }}$ week of May, respectively as compared to check plot where mealybug populations changed from 46.8 individuals/leaf on late April to 54.6, 57.8, 64.5 and 67.5 individuals/leaf in the same dates, respectively. In addition, the results show that the percent reduction of mealybug population in $3^{\text {rd }}$ release plot increased gradually to reach $32.91,51.99$, 67.24 and $74.69 \%$ on the $1^{\text {st }}, 2^{\text {nd }}, 3^{\text {rd }}$ and $4^{\text {th }}$ week of May, respectively.

The second releasing time occurred (after finishing the last inspection of the $1^{\text {st }}$ release level) on late May; the pre-count in the releasing area with mealybug was 17.3 individuals/leaf, while it was also 67.5 individuals/leaf in check trees. The results in Fig. (6) indicated that the number of $P$. citri in the $3^{\text {rd }}$ release plot decreased gradually from 17.3 on late May to $11.8,7.2,5.1$ and 4.1 individuals/leaf on the $1^{\text {st }}, 2^{\text {nd }}, 3^{\text {rd }}$ and $4^{\text {th }}$ week of June, respectively as compared to check plot (mealybug populations changed from 67.5 individuals/leaf on late May to 72.8, 61.7, 58.4 and 51.2 individuals/leaf in the same dates, respectively. In addition, the results show that the percent reduction of mealybug population in $3^{\text {rd }}$ release plot increased gradually to reach $68.76 \%$ on June.

Also, the third releasing time occurred (after finishing the last inspection of the $2^{\text {nd }}$ release level) on late June; the pre-count in the releasing area with mealybug was 4.1 individuals/leaf, while it was also 51.2 individuals/leaf in check trees plot. 

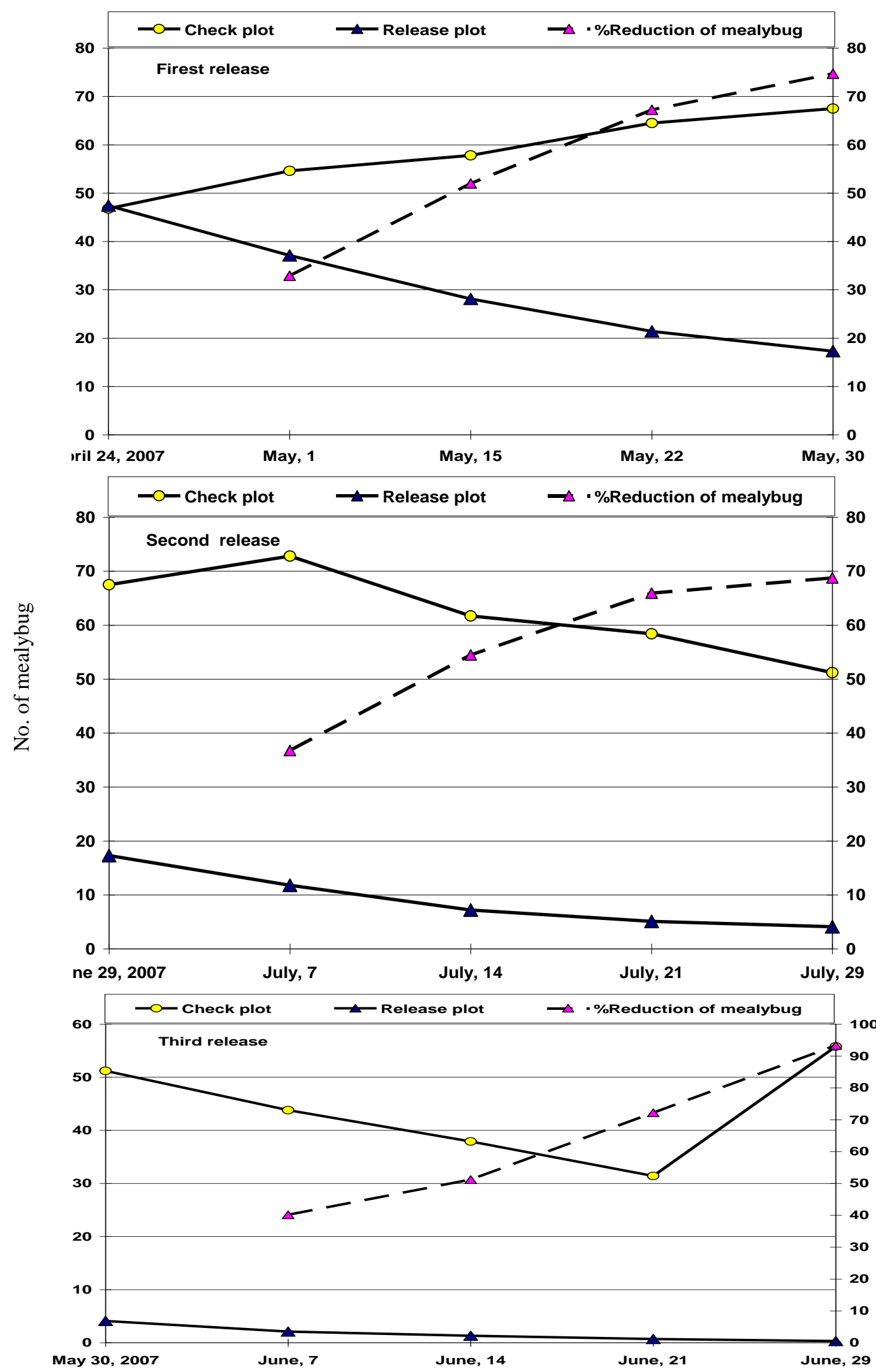

Fig. 6. Population fluctuation in the population numbers of the citrus mealybug, Planococcus citri (Risso) (Homoptera : Pseudococcidae) in the $2^{\text {nd }}$ plot release at level (15 larvae/tree) of the green lacewing, Chrysoperla carnea Steph. (Neuroptera: Chrysopidae), and the corresponding \%reduction of the mealybug density on citrus trees during 2007. 
The results in Fig. (6) indicated that the number of $P$. citri in the $3^{\text {rd }}$ release plot decreased gradually from 4.1 on late June to $2.1,1.3,0.7$ and 0.3 individuals/leaf on the $1^{\text {st }}, 2^{\text {nd }}, 3^{\text {rd }}$ and $4^{\text {th }}$ week of July, respectively as compared to check plot where mealybug populations changed from 51.2 individuals/leaf on late June to $43.8,37.9$, 31.4 and 55.8 individuals/leaf in the same dates, respectively. In addition, the results show that the percent reduction of mealybug population in $3^{\text {rd }}$ release plot increased gradually to reach $93.29 \%$ on July.

Table 1. Percent reduction in the citrus mealybug, Planococcus citri (Risso) (Homoptera : Pseudococcidae) after the successive releasing levels $(5,10$ and 15 larvae/tree) of the green lacewing, Chrysoperla carnea Steph. (Neuroptera: Chrysopidae) on citrus trees during 2006 and 2007.

\begin{tabular}{|c|c|c|c|c|}
\hline \multirow{2}{*}{ Release level } & \multirow{2}{*}{ Release time } & \multicolumn{2}{|c|}{$\%$ Reduction in mealybug population } & \multirow{2}{*}{ Average } \\
\hline & & 2006 & 2007 & \\
\hline \multirow{3}{*}{5} & Late April & 36.68 & 47.39 & 42.04 \\
\hline & Late May & 53.67 & 45.99 & 49.83 \\
\hline & Late June & 66.08 & 56.14 & 61.11 \\
\hline \multirow{3}{*}{10} & Late April & 68.24 & 65.39 & 66.82 \\
\hline & Late May & 53.09 & 46.39 & 49.74 \\
\hline & Late June & 82.75 & 80.86 & 81.81 \\
\hline \multirow{3}{*}{15} & Late April & 71.00 & 74.69 & 72.85 \\
\hline & Late May & 55.71 & 68.76 & 62.24 \\
\hline & Late June & 98.66 & 93.29 & 95.98 \\
\hline $\mathrm{F} 0.05=$ & - & \multicolumn{2}{|c|}{$0.009 \mathrm{~ns}$} & - \\
\hline $\mathrm{LSD}=$ & & \multicolumn{2}{|c|}{ - } & - \\
\hline
\end{tabular}

Statistical analysis in Table (1) revealed differences in responses to the three successive releasing levels of Chrysoperla carnea for management $P$. citri during 2006 an 2007 seasons that proved no significant among the two seasons $(\mathrm{F}=0.009, \mathrm{P}<0.05)$.

\section{REFERENCES}

1. Ali, K. A. H. 2003. Trails for mass-rearing and release for some predacious insects for controlling of pink and spiny bollworms. Ph.D. Fac. Agric. Moshtohor, Benha Branch, Zagazig Univ.

2. Anonymous 2006. Mealybugs and their bio-control. http://www.flora. unconn.edu/imp/scout comb.html.

3. Baker, J. R. 1998. Ornamental and turf insect note 19 (ENT/ort-019). http://www.ces.ncsu.edu/depts/ent/motes/Turf/flower_contents/orn_t19/not19.ht $\mathrm{ml}$. 
4. Cartwirth, B. and H. W. Browning. 1999. Texas citrus mealybug and whiteflies. http://aggie-horticulture.tamu.edu/citrus/12311.htm.

5. Hendrson, C. F. and E. W. Tilton. 1955. Test with acaricides against the brown wheat mite. J. Econ Entomol., 48: 157-161.

6. Hill, D. S. 1983. Planococcus citri (Risso).pp. 217. In Agricultural Insect Pests of the Tropics and Their Control, 2nd Edition. Cambridge University Press, 746 pages.

7. Mangoud, A. A. H. 2006. Manipulation of Leptomastix dactylopii and Cryptolaemus montrouzieri for augmentative release for controlling the citrus mealybug, Planococcus citri on citrus under green house conditions. Egypt, J. Agric. Res., 84 (3): 803-813.

8. Mendel, Z., S. Gross, S. Steinberg, M. Cohen and D. Blumberg. 1998. Trails to control the citrus mealybug in citrus orchards by inundative releases on natural enemies. VIIIth International Symposium on Scale Insect Studies, $41 \mathrm{pp}$.

9. Ortu, S. and Marras P. 1999. Biological control of Planococcus citri (Risso) with Leptomastix dactylopii Howard for reducing insecticides use in citrus in Sardinian. http://www.ejb.org/ feedback/proceedings/05/ortuingl.html.

10. Ridgway, R. L. and S. B. Vinson. 1977. Biological control by augmentation of natural enemies. Plenum Press, New York. 480 pp.

11. SAS Institute 1988. SAS/STAT User`s Guide, Ver. 6.03. SAS Institute Inc., Cary, North Carolina. 
124 BIOLOGICAL CONTROL OF THE CITRUS MEALYBUG, PLANOCOCCUS CITRI (HOMOPTERA: PSEUDOCOCCIDAE) INFESTING CITRUS TREES BY SUCCESSIVE RELEASING WITH DIFFERENT LEVELS OF THE GREEN LACEWING, CHRYSOPERLA CARNEA (NEUROPTERA: CHRYSOPIDAE)

\section{المكافحة الحيوية لبق الموالح الدقيقي عن طريق إطلاق مستويات مختلفة} لمفترس أسد المن علي أثجار الموالح

$$
\begin{aligned}
& \text { معهُ بحوث وقاية النباتات - مركز البحوث الزراعبة - الدقي - جيزة السلام هندي منجود ، كارم أبو زيد حسن علي }
\end{aligned}
$$

في هذا العمل وجد أن مفترس أسد المن لعب دور هام في خفض تعداد بق الموالح الدقيقي

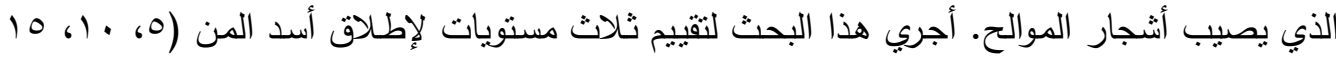

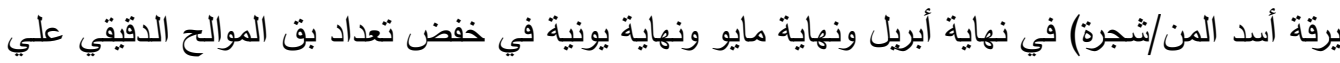

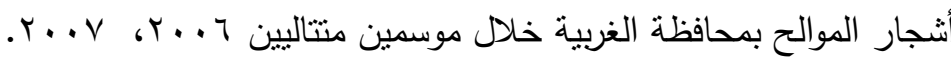
أوضحت النتائج أن معدل الخفض في تعداد البق الدقيقي تزايدت بمرور الوقت حتي وصلت

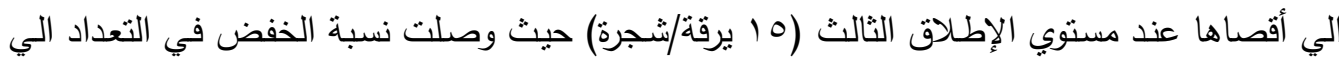

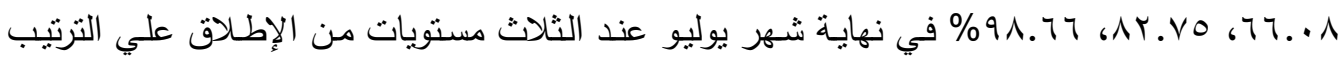

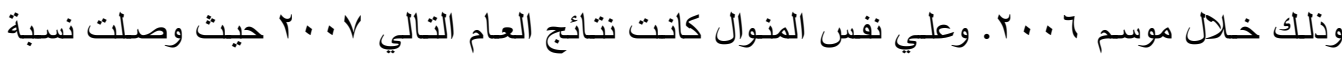

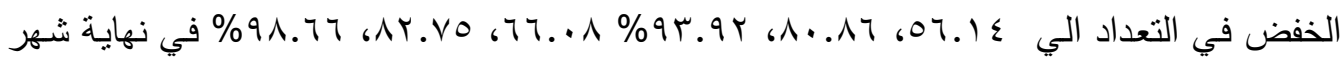
يوليو عند الثلاث مستويات من الإطلاق علي الترتيب. كمت أوضحت النتائج أيضا عدم وجود فروق

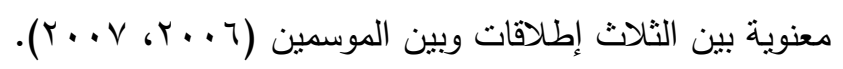

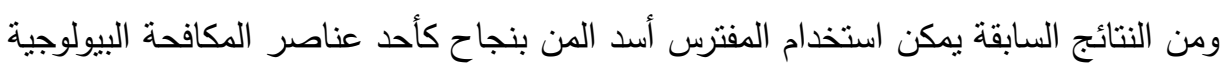
الفعاله في برامج المكافحة المتكاملة لبق الموالح الدقيقي علي أثنجار الموالح. 